\title{
Sistem Informasi Penyedia Layanan Jasa Pengiriman Barang Impor Pada PT Pelita Barat Daya
}

\author{
Yana Iqbal Maulana, M.Kom ${ }^{1}$ \\ ${ }^{1}$ Fakultas Teknologi Informasi, Universitas Bina Sarana Informatika \\ e-mail: ${ }^{1}$ yana.yim@bsi.ac.id

\begin{tabular}{ccc}
\hline Diterima & Direvisi & Disetujui \\
$09-12-2019$ & $12-12-2019$ & $16-12-2019$ \\
\hline
\end{tabular}

\begin{abstract}
Abstrak - PT. Pelita Barat Daya di dirikan pada tanggal 09 Juni 2014 dan berkedudukan di Komplek Gading Bukit Indah Blok SB No 11 Kelapa Gading, Jakarta Utara yang bergerak dibidang penyedia layanan jasa impor barang. Didirikan oleh seorang yang bernama Bapak Ardhi Gilang Harsatya. Dalam kurun waktu tersebut sampai dengan sekarang mereka telah melayani kebutuhan berbagai perusahaaan besar maupun kecil. PT Pelita Barat Daya adalah perusahaan yang bergerak dalam bidang Penyedia Layanan Jasa Pengiriman Barang Impor, PT Pelita Barat Daya membutuhkan adanya sistem informasi penunjang yang dapat memberikan pelayanan memuaskan bagi para pengguna jasa. PT Pelita Barat Daya sampai saat ini belum menggunakan sarana teknologi website sebagai media penyampaian informasi. Sistem yang ada pada PT Pelita Barat Daya saat ini belum efektif karena menerapkan komputer dengan aplikasi pada komputer tertentu yang membuat kinerja karyawan membutuhkan waktu yang lebih lama. Perancangan sistem informasi merupakan solusi terbaik dengan menerapkan sistem informasi berbasis website yang terhubung ke jaringan akan memberikan kelancaran dan kecepatan kerja dalam menyampaikan informasi sehingga tercapai suatu kegiatan yang efektif dan efisien dalam menunjang aktifitas pada perusahaan ini.
\end{abstract}

Kata Kunci: Sistem Informasi; Jasa Pengiriman; Web

Abstract - PT. Pelita Barat Daya was established on June 9, 2014 and is domiciled in the Gading Bukit Indah Complex, SB Block No. 11 Kelapa Gading, North Jakarta, which is engaged in providing goods import services. Founded by a man named Mr. Ardhi Gilang Harsatya. In that period until now they have served the needs of various large and small companies. PT Pelita Barat Daya is a company engaged in the field of Imported Freight Forwarding services, PT Pelita Barat Daya requires a supporting information system that can provide satisfying services for service users until now PT Pelita Barat Daya has not used website technology as a media to deliver the information PT Pelita Barat Daya system is ineffective because it implements certain applications on computers and slowing down employee performance information system design is the best solution by implementing a website-based information system that is connected to the network which will provide smoothness and speed in conveying information. so the job becomes more effective and efficient to support company activities.

Keywords: Information System; Delivery Services; Web

\section{PENDAHULUAN}

PT. Pelita Barat Daya di dirikan pada tanggal 09 Juni 2014 dan berkedudukan di Komplek Gading Bukit Indah Blok SB No 11 Kelapa Gading, Jakarta Utara yang bergerak dibidang penyedia layanan jasa impor barang. Didirikan oleh seorang yang bernama Bapak Ardhi Gilang Harsatya .Dalam kurun waktu tersebut sampai dengan sekarang mereka telah melayani kebutuhan berbagai perusahaaan besar maupun kecil.

PT Pelita Barat Daya adalah sebuah perusahaan yang bergerak di bidang Penyedia Layanan Jasa Pengiriman Barang Impor. Pada kenyataanya, meskipun perusahaan ini sudah cukup lama berkembang dalam perjalanan bisnisnya, namun hal tersebut belum diikuti dengan perkembangan dalam membuat sebuah website.

Berdasarkan permasalahan diatas, untuk itu penulis akan mencoba membantu memberikan referensi kepada perusahaan dengan membuat website dimana didalam sebuah website yang dimana website tersebut bisa diakses oleh semua orang, dengan menggunakan bahasa pemrograman Sublime Text yang meliput Halaman Website dan di halaman website tersebut customer bisa komunikasi tentang Jasa Pengiriman Barang, adapun Form Login yang hanya bisa diakses melalui username 
dan password, dan halaman utama terdapat beberapa menu, diantanya, master data yang di dalamnya ada menu data customer, data mobil, data supir dan data tarif, kemudian menu transaksi pengiriman, menu surat jalan, membuat transaksi pengiriman, membuat surat jalan, membuat laporan pengiriman dan Logout.

Bentuk Sistem yang baik akan sangat dibutuhkan dalam organisasi apapun, sehingga usaha-usaha yang dioprasikan sesuai dengan keinginan yang diharapkan, akan tetapi dengan adanya perkembangan zaman yang sedemikian pesat yang mengakibatkan semua ketentuan dan cara bentuk pengolahan usaha harus dapat sesuai dan pengaturan aktivutas yang baik sering timbul masalah. Melihat semua proses yang terjadi di perusahaan PT Pelita Barat Daya dalam sistem membuat laporan pengiriman. Ada permasalahan tersebut diantaranya:

1. Tidak adanya penggunaan program dalam mengolah hasil laporan pengiriman, dan laporan lainnya, sehingga dalam membuat laporan pengiriman membutuhkan waktu cukup lama.

2. Proses pembuatan laporan sering terlambat karena data atau informasi yang dibutuhkan untuk merekap data hilang atau rusak.

3. Tidak adanya penggunaan sebuah website dalam perusahaan, sehingga perusahaan akan sulit untuk bersaing dengan perusahaan lain dalam hal perkembangan perusahaan.

\section{METODE PENELITIAN}

Metode penelitian adalah langkah dan prosedur yang akan dilakukan dalam pengumpulan data atau informasi guna mendapatkan tujuan dari sebuah penelitian.

A. Teknik Pengumpulan Data

1. Metode Wawancara

Suatu bentuk metode riset yang menggunakan proses tanya jawab dengan mengajukan beberapa pertanyaan kepada pihak yang berkepentingan di bagian dokumen atau biasa disebut di perusahaan tersebut dengan bagian staff dokumen.

2. Metode Observasi

Suatu metode untuk mendapatkan data dengan melakukan pengamatan dan melaksanakan pencatatan secara sistematis terhadap unsurunsur yang akan diteliti dengan melakukan peninjauan langsung kepada PT. Pelita Barat Daya, mengenai jasa pengiriman barang impor.

3. Studi Kepustakaan

Penulis mempelajari buku-buku dan catatancatatan yang didapatkan penulis selama masa perkuliahan, yang menunjang penulisan dalam makalah ini, dan mempelajari informasi yang diperoleh dari PT. Pelita Barat Daya.

\section{B. Model Pengembangan Sistem}

Metode pengembangan sistem yang digunakan dalam Sistem Informasi Penyedia Layanan Jasa Pengiriman Barang Impor Pada PT Pelita Barat Daya ini adalah model Systems Development Life Cycle (SDLC) dengan pendekatan metode waterfall.

Metode Waterfall yaitu analis dan pengguna melanjutkan secara berurutan dari satu tahap ke tahap berikutnya. Metodologi pengembangan waterfall memiliki keuntungan mengidentifikasi requirement jauh sebelum pemrograman dimulai dan membatasi perubahan requirement sebagai hasil proyek. Kelemahan utama waterfall adalah bahwa desain harus benar-benar ditentukan sebelum program dimulai, diperlukan waktu yang lama antara selesainya usulan sistem dalam tahap analisis dan penyerahan sistem, dan pengujian diolah hampir menjadi ketinggalan jaman dalam tahap implementasi.

\section{HASIL DAN PEMBAHASAN 1. Analisa Kebutuhan Software}

Analisa kebutuhan software merupakan langkah awal atau kemampuan yang harus dimiliki perangkat lunak yang digunakan untuk mengetahui gambaran perangkat yang dihasilkan sesuai dengan apa yang diinginkan pengembang software tersebut. Analisa kebutuhan software ini dapat menyelesaikan permasalahan yang ada sekarang juga digunakan untuk mutu kerja karyawan.

\section{A. Tahapan Analisis}

Halaman Admin

A.1. Admin Login

A.2. Admin Mengelola Master Data

A.3. Admin Mengelola Data Customer

A.4. Admin Mengelola Data Mobil

A.5. Admin Mengelola Data Tarif

A.6. Admin Mengelola Data Supir

A.7. Admin Mengelola Transaksi Pengiriman

A.8. Admin Membuat Laporan Pengiriman

A.9. Admin Membuat Surat Jalan

A.10. Admin Logout 


\section{B. Use Case Diagram}

1. Use Case Diagram Halaman Admin

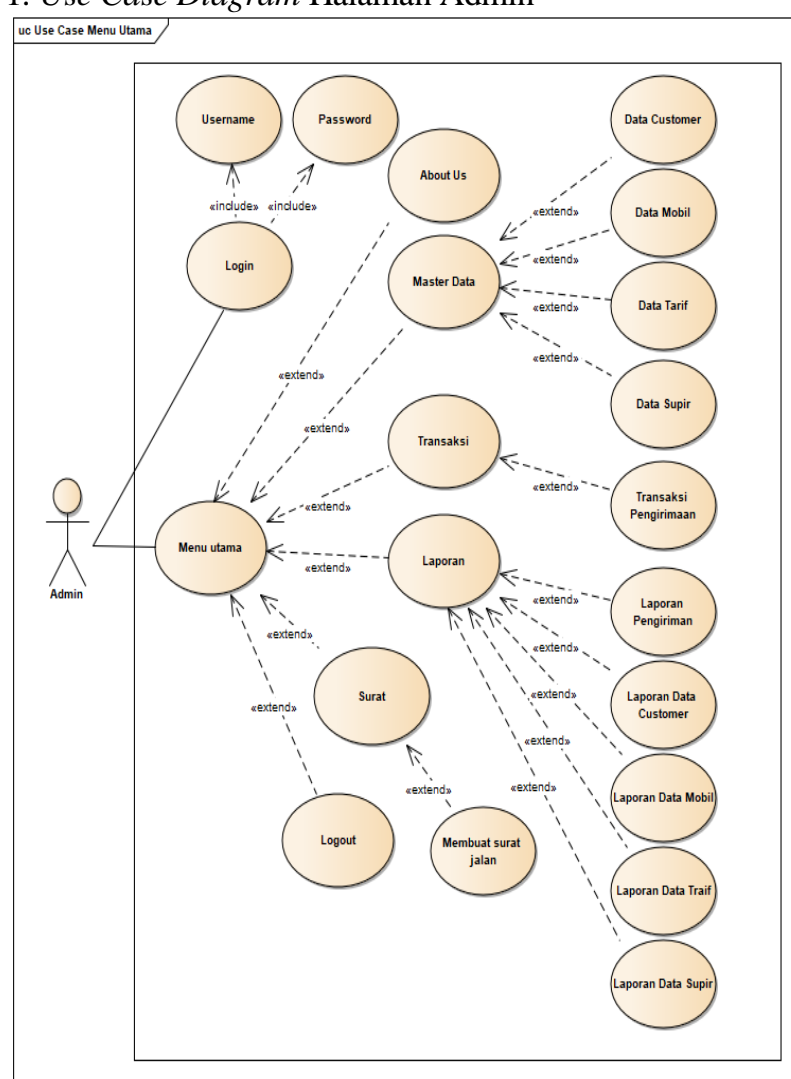

Sumber: Hasil Penelitian (2018)

Gambar 1. Use Case Diagram Halaman Admin

C. Activity Diagram

1. Activity Diagram Data Customer

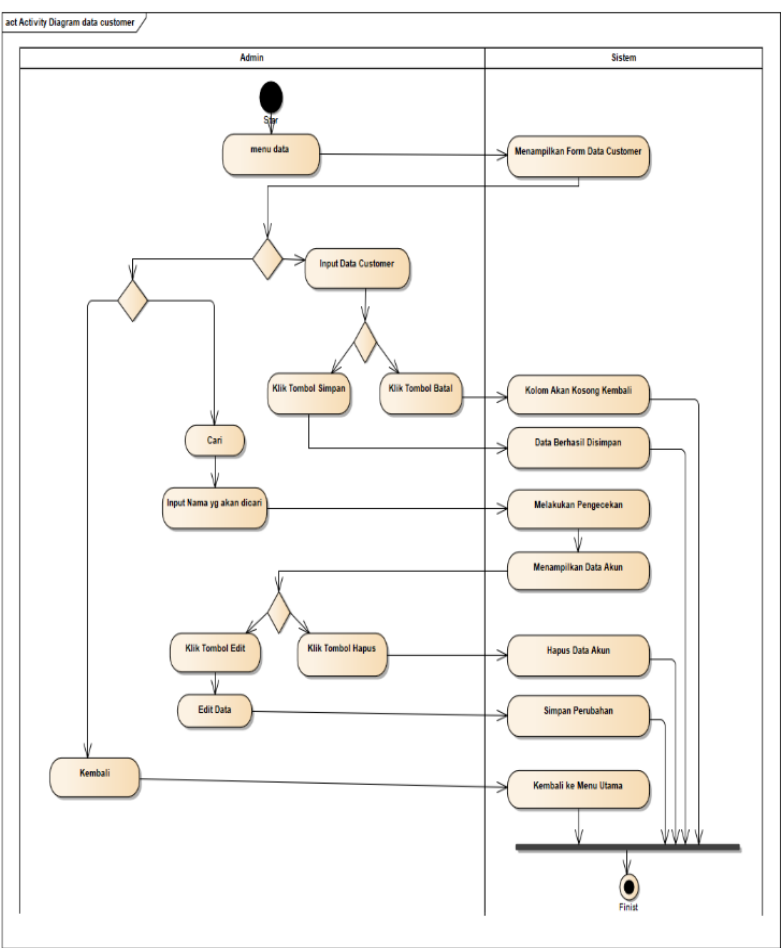

Sumber: Hasil Penelitian (2018)

Gambar 2. Activity Diagram Data Customer

\section{Activity Diagram Data Tarif}

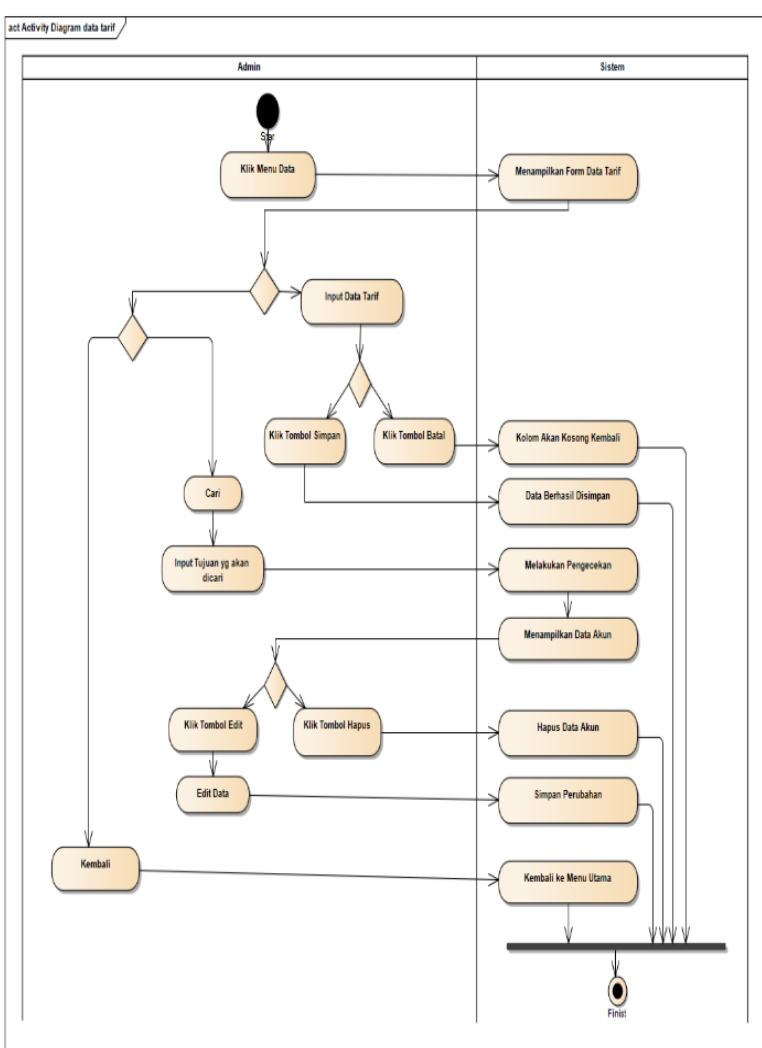

Sumber: Hasil Penelitian (2018)

Gambar 3. Activity Diagram Data Tarif

\section{Activity Diagram Transaksi Pengiriman}

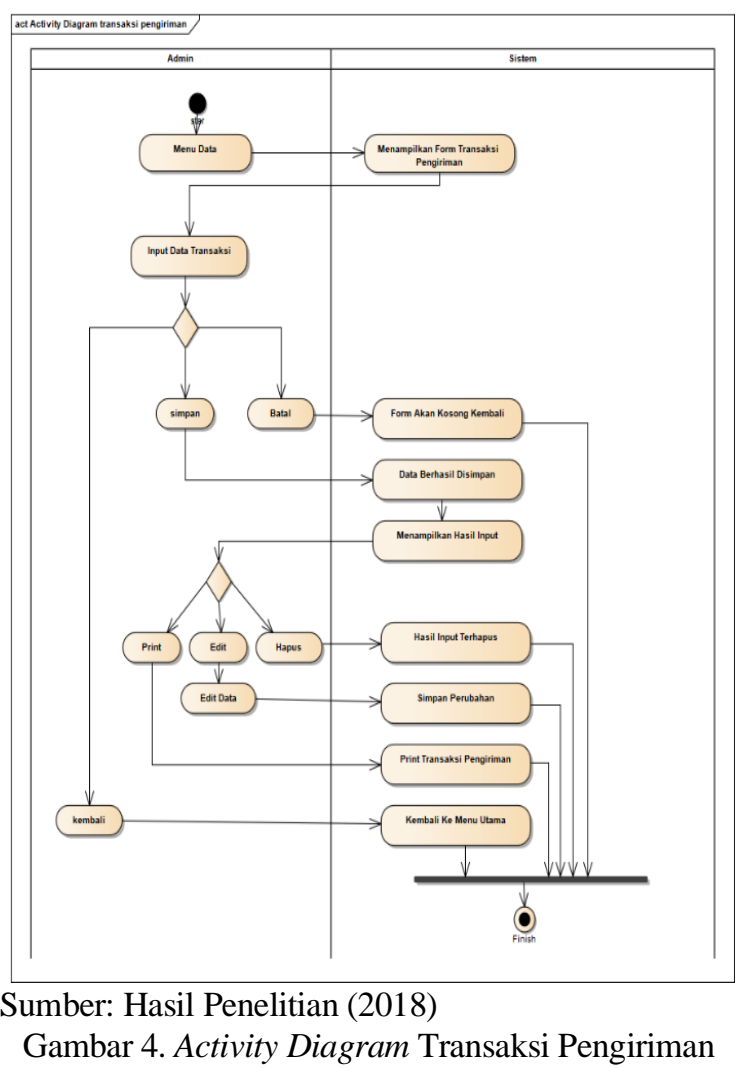




\section{Activity Diagram Surat Jalan}

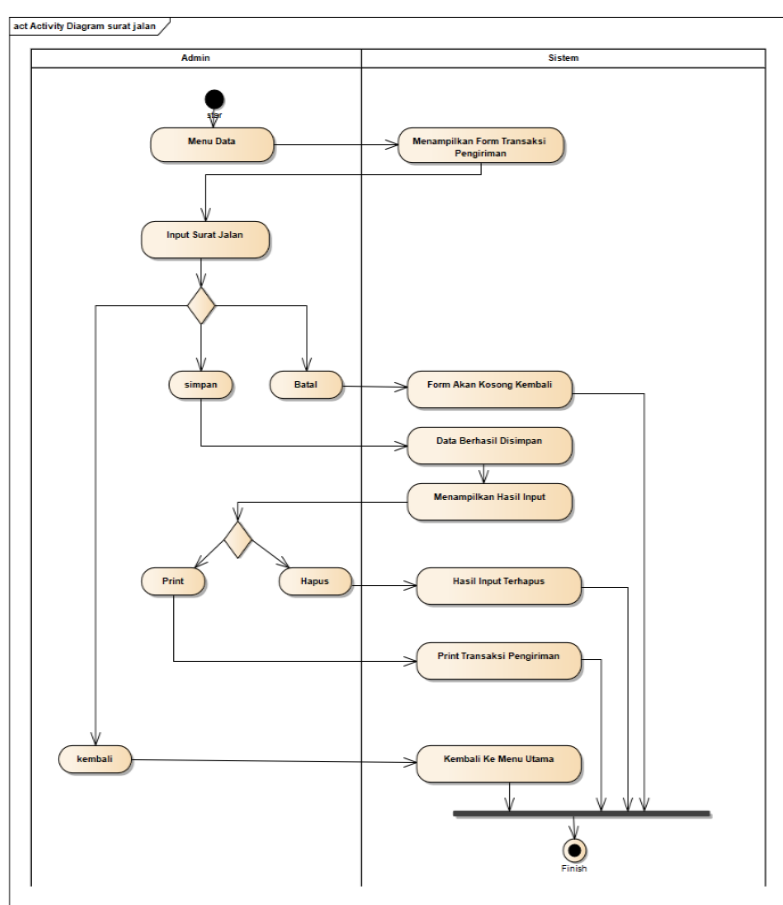

Sumber: Hasil Penelitian (2018)

Gambar 5. Activity Diagram Surat Jalan

\section{Entity Relationship Diagram}

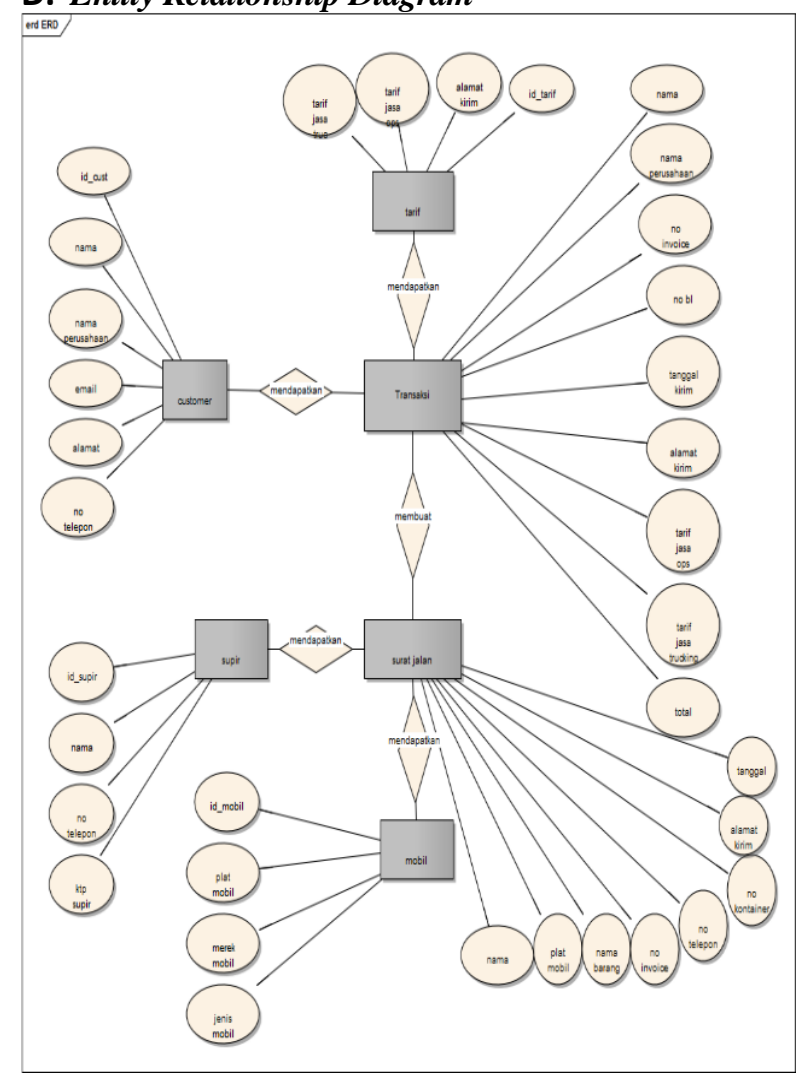

Sumber: Hasil Penelitian (2018)

Gambar 6. Entity Relationship Diagram

\section{E. Spesifikasi File}

1. Spesifikasi File Supir

$\begin{array}{ll}\text { Nama Database } & \text { : db_impor } \\ \text { Nama file } & \text { : supir } \\ \text { Tipe File } & \text { : Master } \\ \text { Akses File } & \text { : Random } \\ \text { Panjang Record } & : \text { 70 Karakter } \\ \text { Filed Key } & \text { : id_supir }\end{array}$

Tabel 1.

Spesifikasi File Tabel Supir

\begin{tabular}{|c|l|l|l|l|l|}
\hline No & Elemen Data & Akronim & Tipe & Panjang & Keterangan \\
\hline 1 & Id_supir & id_supir & Vaerchar & 20 & Primary Key \\
\hline 2 & Nama & Nm & Varchar & 20 & \\
\hline 3 & No telepon & No tlp & Char & 15 & \\
\hline 4 & Ktp supir & Ktp supir & Char & 15 & \\
\hline
\end{tabular}

Sumber: Data Penelitian (2018)

2. Spesifikasi File Mobil
Nama Databas
: db_impor
Nama file
: mobil
Tipe File
: Master
Akses File
: Random
Panjang Record
: 50 Karakter
Filed Key
: id_mobil

Tabel 2.

Spesifikasi File Tabel Mobil

\begin{tabular}{|c|l|l|c|c|c|}
\hline No & Elemen Data & Akronim & Tipe & Panjang & Keterangan \\
\hline 1 & Identitas mobil & Id_mobil & Char & 15 & Primary Key \\
\hline 2 & Plat Mobil & Plat mobil & Char & 10 & \\
\hline 3 & Merek Mobil & Mrk mobil & Char & 15 & \\
\hline 4 & Jenis Mobil & Jns mobil & Char & 10 & \\
\hline
\end{tabular}

Sumber: Data Penelitian (2018)

\section{F. Deployment Diagram}

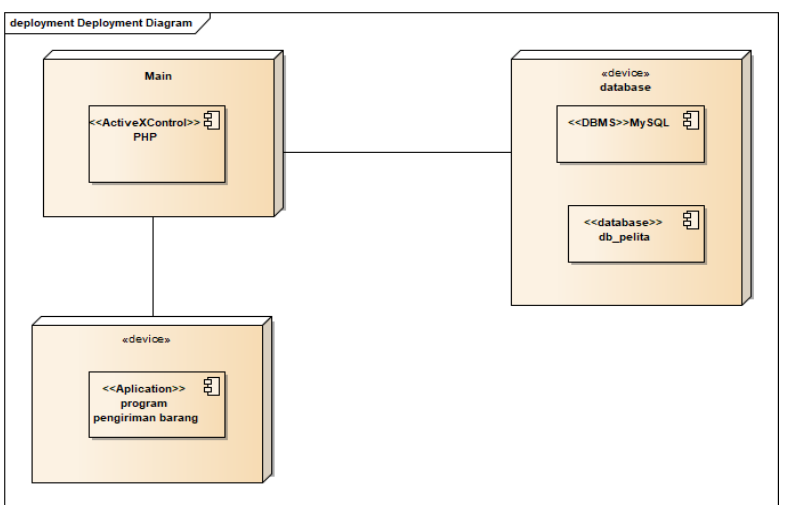

Sumber: Hasil Penelitian (2018)

Gambar 7. Deployment Diagram 
G. User Interface

\section{Tampilan Form Login}

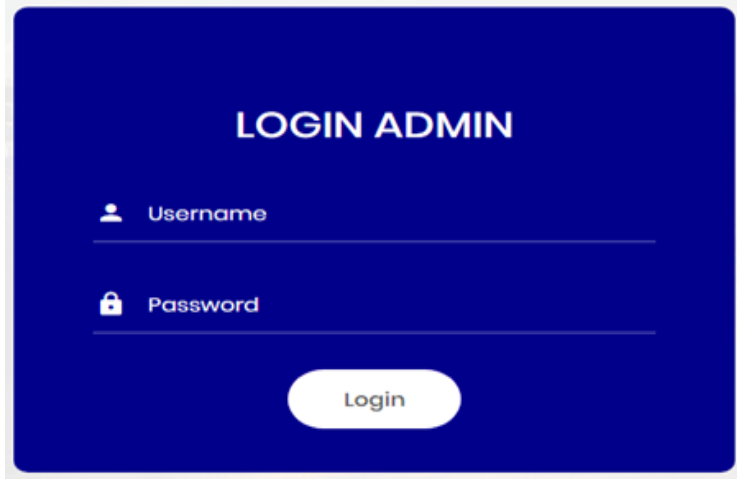

Sumber: Hasil Penelitian (2018)

Gambar 8. Tampilan Form Login

\section{Tampilan Halaman Utama}

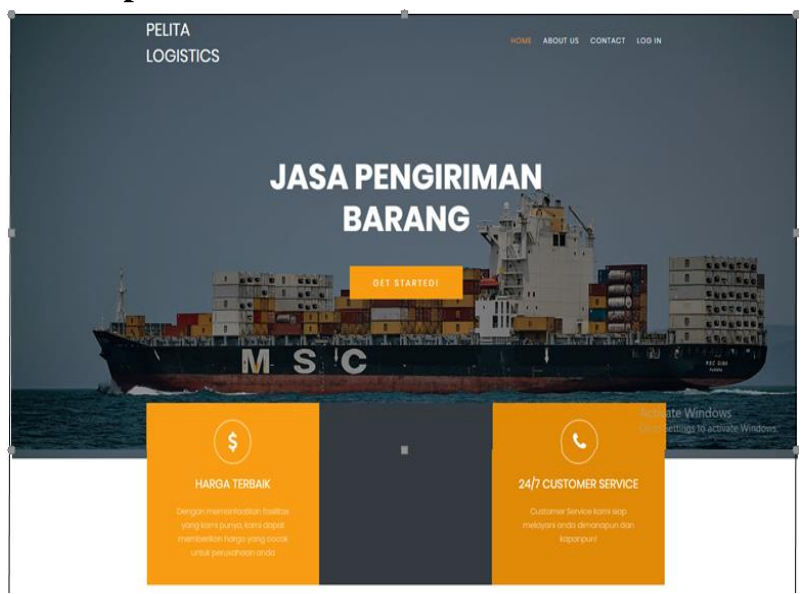

Sumber: Hasil Penelitian (2018)

Gambar 9. Tampilan Halaman Utama

Tabel 3.

Hasil Pengujian Black Box Testing Form Login Admin

\begin{tabular}{|c|c|c|c|c|c|}
\hline $\begin{array}{l}\mathrm{N} \\
\mathrm{o} .\end{array}$ & $\begin{array}{l}\text { Skenari } \\
\mathrm{o} \\
\text { Pengujia } \\
\mathrm{n}\end{array}$ & $\begin{array}{l}\text { Tes } \\
\text { Case }\end{array}$ & $\begin{array}{l}\text { Hasil } \\
\text { yang } \\
\text { diharapka } \\
\mathrm{n}\end{array}$ & $\begin{array}{l}\text { Hasil } \\
\text { Penguj } \\
\text { ian }\end{array}$ & $\begin{array}{l}\text { Kesimp } \\
\text { ulan }\end{array}$ \\
\hline 1. & $\begin{array}{l}\text { Nama } \\
\text { User } \\
\text { dan } \\
\text { passwor } \\
\text { d tidak } \\
\text { diisi } \\
\text { kemudia } \\
\text { n klik } \\
\text { tombol } \\
\text { login }\end{array}$ & $\begin{array}{l}\text { Nama } \\
\text { User } \\
\text { (koson } \\
\text { g) } \\
\text { Passwo } \\
\text { rd: } \\
\text { (koson } \\
\text { g) }\end{array}$ & $\begin{array}{l}\text { Sistem } \\
\text { akan } \\
\text { menolak } \\
\text { akses dan } \\
\text { menampil } \\
\text { kan Enter } \\
\text { Usernam } \\
\text { e \& } \\
\text { Password }\end{array}$ & $\begin{array}{l}\text { Sesuai } \\
\text { Harapa } \\
\text { n }\end{array}$ & Valid \\
\hline 2. & $\begin{array}{l}\text { Mengeti } \\
\text { kan } \\
\text { nama } \\
\text { user dan } \\
\text { passwor } \\
\text { d tidak } \\
\text { diisi } \\
\text { atau } \\
\text { kosong } \\
\text { kemudia } \\
\text { n klik } \\
\text { tombol } \\
\text { login }\end{array}$ & $\begin{array}{l}\text { Nama } \\
\text { user } \\
\text { Admin } \\
\text { Passwo } \\
\text { rd } \\
\text { kosong }\end{array}$ & $\begin{array}{l}\text { Sistem } \\
\text { akan } \\
\text { menolak } \\
\text { akses dan } \\
\text { menampil } \\
\text { kan Enter } \\
\text { Password }\end{array}$ & $\begin{array}{l}\text { Sesuai } \\
\text { harapa } \\
n\end{array}$ & Valid \\
\hline
\end{tabular}

\begin{tabular}{|c|c|c|c|c|c|}
\hline 3. & $\begin{array}{l}\text { Nama } \\
\text { user } \\
\text { tidak } \\
\text { diisi } \\
\text { (kosong } \\
\text { ) dan } \\
\text { passwor } \\
\text { d diisi } \\
\text { kemudia } \\
\text { n klik } \\
\text { tombol } \\
\text { login } \\
\end{array}$ & $\begin{array}{l}\text { Nama } \\
\text { user } \\
\text { (koson } \\
\text { g) } \\
\text { Passwo } \\
\text { rd alwi }\end{array}$ & $\begin{array}{l}\text { Sistem } \\
\text { akan } \\
\text { menolak } \\
\text { akses dan } \\
\text { menampil } \\
\text { kan Enter } \\
\text { Usernam } \\
\text { e }\end{array}$ & $\begin{array}{l}\text { Sesuai } \\
\text { harapa } \\
n\end{array}$ & Valid \\
\hline 4. & $\begin{array}{l}\text { Mengeti } \\
\text { kan } \\
\text { salah } \\
\text { satu } \\
\text { pada } \\
\text { nama } \\
\text { user } \\
\text { atau } \\
\text { passwor } \\
\text { d } \\
\text { kemudia } \\
\text { n klik } \\
\text { tombol } \\
\text { login }\end{array}$ & $\begin{array}{l}\text { Nama } \\
\text { user } \\
\text { Admin } \\
\text { Passwo } \\
\text { rd } \\
123456\end{array}$ & $\begin{array}{l}\text { Sistem } \\
\text { akan } \\
\text { menolak } \\
\text { akses } \\
\text { akan } \\
\text { kembali } \\
\text { diarahkan } \\
\text { ke } \\
\text { halaman } \\
\text { login dan } \\
\text { menampil } \\
\text { kan } \\
\text { Usernam } \\
\text { e dan } \\
\text { Password } \\
\text { yang } \\
\text { anda } \\
\text { masukka } \\
\text { n salah }\end{array}$ & $\begin{array}{l}\text { Sesuai } \\
\text { harapa } \\
n\end{array}$ & Valid \\
\hline 5. & $\begin{array}{l}\text { Mengeti } \\
\text { kan } \\
\text { nama } \\
\text { user dan } \\
\text { passwor } \\
\text { d } \\
\text { dengan } \\
\text { data } \\
\text { yang } \\
\text { benar } \\
\text { kemudia } \\
\text { n klik } \\
\text { tombol } \\
\text { login }\end{array}$ & $\begin{array}{l}\text { Nama } \\
\text { user } \\
\text { Admin } \\
\text { Passwo } \\
\text { rd } \\
1234\end{array}$ & $\begin{array}{l}\text { Sistem } \\
\text { akan } \\
\text { menerima } \\
\text { akses } \\
\text { login dan } \\
\text { akan } \\
\text { menampil } \\
\text { kan } \\
\text { Halaman } \\
\text { Utama } \\
\text { Sistem }\end{array}$ & $\begin{array}{l}\text { Sesuai } \\
\text { harapa } \\
n\end{array}$ & Valid \\
\hline
\end{tabular}

Sumber: Hasil Penelitian (2018)

\section{KESIMPULAN}

Dari hasil penelitian yang penulis lakukan, maka dapat diambil kesimpulan: Dengan membuat Sistem Web ini maka PT Pelita Barat Daya mampu bersaing dengan perusahaanperusahaan lainnya dalam hal promosikan jasa pengiriman barang impor dan akan sangat membantu bagi customer yang akan menggunakan jasa PT Pelita Barat Daya Untuk bertanya langsung mengenai Jasa Pengiriman Barang Impor ini. Dengan dibangunnya sistem yang terkomputerisasi pada PT Pelita Barat Daya Jakarta maka aktivitas pada perusahaan tersebut seperti pembuatan transaksi pengiriman barang dan pembuatan laporan dapat dengan lebih efisien dan efektif. Setelah dibangunnya sistem yang terkomputerisasi dapat meminimalisir kesalahan-kesalahan yang sebelumnya terjadi pada PT Pelita Barat Daya. Diharapkan dengan adanya sistem yang dibangun dapat meningkatkan kinerja perusahaan dan mempercepat operasional perusahaan. 


\section{REFERENSI}

Ahmad, N. H., \& Firmansyah, E. A. (2018). Suatu Tinjauan Atas Prosedur Penerimaan Barang Impor dari Pelabuhan Muat dengan Status Peti Kemas Full Container Load (FCL) Keywords : Customs , CIF , FCL , Freight Forwarding , Import.

Berata, I.K.oko.(2014) Expor Impor Jakarta: Raih Asah Sukses

Dennis, Wixom, \& Tegarden. (2015). System Analysis \& Design An Object-Oriented Approach with UML. Retrieved from http://store.visible.com/Wiley.aspx

Farell, G., Saputra, H. K., \& Novid, I. (2018). Rancang Bangun Sistem Informasi Pengarsipan Surat Menyurat (Studi Kasus Fakultas Teknik Unp). Jurnal Teknologi Informasi Dan Pendidikan (JTIP), 11(2), 5662.

Hastanti, R. P., Eka, B., Indah, P., \& Wardati, U. (2015). Sistem Penjualan Berbasis Web ( ECommerce ) Pada Tata Distro Kabupaten Pacitan. Jurnal Bianglala Informatika, 3(2), 19.

Hidayat, R. (2017). Aplikasi Penjualan Jam Tangan Secara Online. Jurnal Teknik Komputer,3(2),90-96.Retrievedfrom http://ejournal.bsi.ac.id/ejurnal/index.php/jtk/a rticle/view/1842/1529
Mustaqbal, M. S., Firdaus, R. F., \& Rahmadi, H. (2015). Pengujian Aplikasi Menggunakan Black Box Testing Boundary Value Analysis (Studi Kasus: Aplikasi Prediksi Kelulusan SNMPTN), I(3), 34

Maulana, Y. I., Studi, P., \& Informatika, M. (2017). Perancangan Perangkat Lunak Sistem informasi Pendataan Guru dan Sekolah (Sindaru) Pada. 13(1), 21-27.

Noor Hasan, S. A. (2015). Perancangan Sistem Informasi Rawat Jalan Berbasis Web Pada Puskesmas Winong. 3(1), 28-34.

Rosa, A., \& M.Shalahuddin. (2014). REKAYASA PERANGKAT LUNAK. Bandung: Informatika Bandung.

Palendera, Y., Fernando, Y., \& Rizkiono, S. D. (2019). Game Detektif Resimen Mahasiswa Batalyon 209 Teknokrat Gajah Lampung. Jurnal Teknoinfo, 13(1), 46. https://doi.org/10.33365/jti.v13i1.197

Utama, D. W., Putra, I. G. L. A. R., \& Satwika, I. P. (2019). Rancang Bangun Sistem Informasi Pemesanan Custom Furniture Berbasis Website. J-SAKTI (Jurnal Sains Komputer Dan Informatika), 3(1), 53. https://doi.org/10.30645/j-sakti.v3i1.96 